\title{
Detección molecular del virus del distemper canino en casos clínicos de caninos domésticos no vacunados y evaluación de factores de riesgo
}

\author{
MOLECULAR DETECTION OF CANINE DISTEMPER VIRUS IN CLINICAL CASES FROM \\ UNVACCINATED DOMESTIC DOGS AND ASSESSMENT OF RISK FACTORS
}

Andrea Soto R. ${ }^{1}$, Luis R. Luna E. ${ }^{1}$, Raúl Rosadio A. ${ }^{1}$, Lenin Maturrano H.,3

\section{Resumen}

El distemper canino (DC) es una infección vírica causada por un Morbilivirus de la familia Paramyxoviridae. Puede generar sintomatología digestiva, respiratoria y nerviosa, dependiendo de la cepa infectante. Este estudio estuvo destinado a detectar el virus del DC a través de la técnica de RT-PCR y analizar los datos recolectados para tener una visión actual del comportamiento de este virus en la zona de Lima, Perú. Se trabajó con muestras de sangre entera recolectadas entre junio de 2012 y enero de 2015 de 52 caninos no vacunados con signos clínicos compatibles con distemper canino. Se logró amplificar la nucleoproteína de 287 pb en el $32.7 \%$ (17/52) de las muestras analizadas, encontrando, además, una mayor detección del virus, aunque no significativa, en individuos que manifestaban signos clínicos sistémicos (signos respiratorios y digestivos vs nerviosos) y dentro del rango etario de 1.5-4 meses.

Palabras clave: distemper canino; detección molecular; PCR

\section{Abstract}

The canine distemper (CD) is a viral infection caused by a Morbillivirus of the family Paramyxoviridae. It can generate digestive, respiratory, and nervous symptomatology, depending on the infecting strain. This study was designed to detect the CD virus

\footnotetext{
${ }^{1}$ Laboratorio de Microbiología y Parasitología Veterinaria, Facultad de Medicina Veterinaria, Universidad Nacional Mayor de San Marcos, Lima, Perú

${ }^{2}$ Laboratorio de Zootecnia y Producción Agropecuaria, Facultad de Medicina Veterinaria, Universidad Nacional Mayor de San Marcos, Lima, Perú

${ }^{3}$ E-mail: amaturranoh@unmsm.edu.pe
}

Recibido: 30 de agosto de 2017

Aceptado para publicación: 19 de mayo de 2018 
through the RT-PCR technique and perform the analysis of the data collected to have a current view of the behavior of this virus in Lima, Peru. Whole blood samples from 52 unvaccinated canines with clinical signs compatible with canine distemper were collected between June 2012 and January 2015. The nucleoprotein of 287 bp was successfully amplified in $32.7 \%(17 / 52)$ of the samples analyzed. In addition, it was found a greater detection of the virus, but not significative, in individuals that manifested systemic clinical signs (respiratory and digestive signs vs nervous) and within the age range of 1.5-4 months.

Key words: canine distemper; molecular detection; nucleoprotein; PCR

\section{INTRODUCCIÓN}

El virus del distemper canino (CDV) pertenece al género Morbilivirus, familia Paramixoviridae, junto con otros virus causantes de enfermedades en mamíferos, como el virus del distemper focino, virus del sarampión, virus de la peste bovina (rinderpest), virus de la peste de los pequeños rumiantes (Peste de petits ruminants) y otros morbilivirus causantes de enfermedades en delfines y ballenas (Barret, 1999). Este virus presenta envoltura, contiene una molécula de ARN de hebra simple de sentido negativo y de aproximadamente $15 \mathrm{~Kb}$, el cual está asociado a una nucleoproteína (NP), siendo el gen que codifica esta proteína un blanco idóneo para el diagnóstico del virus mediante métodos moleculares, particularmente la RTPCR (Frisk et al., 1999; Jozwik y Frymus, 2002).

El CDV es el agente causal de una enfermedad sistémica en perros, conocido como distemper canino (DC), moquillo o enfermedad de Carré, el cual afecta un rango importante de órganos incluyendo tejidos linfoides, piel, encéfalo y tractos intestinal y respiratorio, lo cual se traduce en una variedad de síntomas de carácter respiratorio, entérico y nervioso (Blancou, 2004; Martella et al., 2008). El CDV tiene la capacidad de infectar una amplia gama de hospederos, siendo los mamíferos carnívoros de las familias Canidae, Felidae, Procyonidae y Mustelidae los más afectados (Deem et al., 2000).
Dentro de la patogenia de esta enfermedad, se conoce que la principal vía de infección de este virus es a través de secreciones orales o nasales que se dispersan en forma de aerosoles o por contacto de individuos afectados con susceptibles (Fenner et al., 1992). El órgano de replicación inicial es el tejido linfoide del tracto respiratorio superior, dispersándose posteriormente a todo el organismo en las células mononucleares del torrente sanguíneo, como el sistema respiratorio, digestivo y nervioso, dependiendo del estado inmunitario del animal, produciendo neumonía, gastroenteritis, alteraciones en la piel y afección del sistema nervioso central (Beineke et al., 2009; Greene, 2012).

La introducción de cepas vacunales a base de virus vivo modificado ha permitido mantener bajo control la enfermedad en caninos domésticos; sin embargo, pese a la alta tasa de cobertura vacunal en la población susceptible, se sigue presentando esta enfermedad, evidenciándose diferencias antigénicas entre las cepas de campo y vacunales (Mochizuki et al., 1999; Jozwik y Frimus, 2002; Panzera et al., 2011, 2014).

Los métodos de diagnóstico que emplean la biología molecular, como la PCR (reacción en cadena de la polimerasa), han contribuido con el diagnóstico de esta enfermedad en animales. La técnica de RT-PCR, dada su alta sensibilidad, ha sido empleada en la detección de este virus en diferentes tipos de muestras biológicas y diferentes estadios de la enfermedad (Frisk et al., 1999). 
El presente trabajo tuvo como objetivo utilizar la técnica de RT-PCR en la detección de CDV en perros con signos clínicos compatibles con la enfermedad y correlacionar estos datos con signos clínicos específicos, edad y la estación del año en que la muestra fue recolectada, para tener una visión más actual del desenvolvimiento de la enfermedad en la zona de Lima, Perú.

\section{Materiales y Métodos}

\section{Muestreo de Animales}

Las muestras de animales fueron de canes no vacunados procedentes de varios distritos de Lima Metropolitana, principalmente de La Molina, El Agustino, Lima Cercado, Miraflores, San Borja, San Luis y Ate. Se registró la edad, sexo, raza y estación del año. El procesamiento y análisis de las muestras se realizaron en las instalaciones de la Sección de Biología y Genética Molecular de la Facultad de Medicina Veterinaria de la Universidad Nacional Mayor de San Marcos.

Se colectaron muestras de sangre entera de animales no vacunados con signos clínicos compatibles con distemper canino (proceso respiratorio, digestivo, nervioso, depresión o inapetencia), entre junio de 2012 y enero de 2015. La elección de animales no vacunados se debió a la posible interferencia del virus vacunal con el virus de campo en la detección por RT-PCR, pudiéndose obtener resultados falsos positivos (Stephensen et al., 1997). Se usó la fórmula de estimación de tamaño muestral a partir de una proporción para poblaciones infinitas, utilizando un nivel de confianza del $90 \%$ y una prevalencia previa de $26 \%$ (Veliz, 2004) y un máximo de error admisible de 0.1 , obteniéndose un tamaño de muestra mínimo de 52 individuos.

Las muestras de sangre se tomaron por punción de la vena cefálica, safena o yugular recolectándose entre 1 y $3 \mathrm{ml}$ de sangre en tubos tipo Vacutainer con EDTA por animal. Las muestras fueron transportadas en hielo para luego ser almacenadas a $-80^{\circ} \mathrm{C}$ en el laboratorio para su conservación hasta el momento de su procesamiento.

\section{Extracción de ARN Viral}

Para la extracción de ARN se usaron $500 \mu 1$ de sangre entera, los cuales fueron lavados sucesivamente con agua libre de nucleasas para eliminar los eritrocitos y la hemoglobina, obteniéndose un pellet constituido mayoritariamente por células blancas. Estas células fueron sometidas a shock térmico con el fin de romper las paredes celulares empleando nitrógeno líquido y un bloque térmico a $56^{\circ} \mathrm{C}$. Posteriormente, el sobrenadante obtenido fue usado para realizar la extracción de ARN con el kit QIAamp ${ }^{\circledR}$ Viral RNA de QIAGEN ${ }^{\circledR}$, siguiendo el instructivo del fabricante. Como control positivo se usó la vacuna a virus vivo atenuado Vanguard DA2L (Pfizer).

\section{RT-PCR}

Para la detección de los ácidos nucleicos virales se usaron los cebadores descritos por Frisk et al. (1999), que amplificaron un fragmento de $287 \mathrm{bp}$ del gen de la nucleoproteína viral, los cuales son universales para todos los Morbilivirus. Se empleó el GeneAmp ${ }^{\circledR}$ Gold RNA PCR Reagent Kit para la realización de la retrotranscripción (RT) y la PCR en un solo paso (RT-PCR one step).

\section{Análisis de la Información}

Los resultados fueron expresados en proporciones. Se usó la prueba de $\mathrm{X}^{2}$ de independencia para determinar asociaciones entre la detección viral por RT-PCR y alguna categoría o factor de riesgo específico. Los datos colectados (signos clínicos, edad, sexo y estación del año) de cada animal se expresaron en cuadros y fueron analizados y correlacionados posteriormente. 
Los signos clínicos fueron estratificados en seis categorías (Cuadro 1) y los signos clínicos sistémicos fueron divididos en tres subcategorías (Cuadro 2). Así mismo, las edades se agruparon en $0-1.5,>1.5-4,>4-12$, $>12$ meses y ND (no determinado), el sexo fue considerado como macho y hembra, y la estación del año en que se recolectaron las muestras fueron verano, otoño, invierno, primavera.

\section{Resultados}

Al análisis de las 52 muestras, 17 (32.7\%) fueron positivas al distemper canino por la prueba de RT-PCR, amplificándose el fragmento de $287 \mathrm{bp}$ del gen N (Figura 1). Con base a los signos clínicos presentados en los 52 animales al momento de la toma de muestra, se tuvieron más animales agrupados en las categorías I, IV y III (Cuadro 3). En forma similar, también fueron detectados más animales positivos al CDV en estas categorías, aunque no hubo relación significativa entre la sintomatología de los animales con la detección del virus por PCR ( $\mathrm{p}>0.05)$.

La distribución de los animales según la clasificación por signos sistémicos se muestra en el Cuadro 4. Se encontró una mayor frecuencia de animales con signos tanto res-

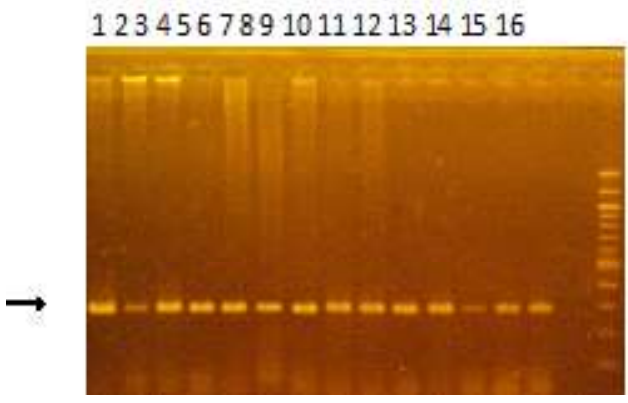

Figura 1. Muestras positivas a la amplificación del fragmento de 287 bp por la técnica de RT-PCR para la detección del virus del distemper canino. Carril 2-14: Muestras positivas, Carril 1: Control positivo, Carril 15: Control negativo, Carril 16: Marcador de peso molecular de $100 \mathrm{bp}$ piratorios como digestivos, así como una mayor proporción de positivos en esa subcategoría; sin embargo, a la prueba de $\mathrm{X}^{2}$ de independencia no hubo relación significativa entre los signos sistémicos con la detección del virus ( $\mathrm{p}>0.05)$. En el Cuadro $4 \mathrm{y}$ en el análisis estadístico no se consideraron a cuatro animales que presentaban solo signos clínicos nerviosos o nerviosos e hiperqueratosis nasal / plantal, por no tratarse de signos sistémicos.

La mayor proporción de animales estuvo en el rango etario de 1.5-4 meses (Cuadro 5), no hallándose relación significativa entre los rangos etarios y la detección del virus ( $>0.05$ ). El mayor número de muestras fue colectado en primavera (22), seguida de verano (15), presentándose los casos positivos mayormente en verano (7); sin embargo, tampoco se halló asociación estadística entre estaciones con la detección del virus $(\mathrm{p}>0.05)$ (Cuadro 6).

\section{Discusión}

El CDV es una de las principales causas de muerte en caninos domésticos en el mundo (Céspedes et al., 2010) y en el Perú se encuentra ampliamente difundido, siendo motivo de consulta frecuente en las clínicas de animales de compañía. El diagnóstico de esta enfermedad suele ser apenas basado en los signos clínicos debido a los altos costos de los análisis de laboratorio que poseen una sensibilidad y especificidad variables. Por ello, el objetivo de este estudio fue utilizar la prueba de RT-PCR para la detección del CDV, conocida por su alta sensibilidad y especificidad (Frisk et al., 1999).

El $32.7 \%$ de animales positivos a la prueba de RT-PCR es menor al $50 \%$ de detección de otros estudios que también utilizaron muestras de sangre (Frisk et al., 1999; Gámiz et al., 2011); escenario que difiere mucho al emplearse muestras de orina o secreciones conjuntivales donde se obtienen mayores porcentajes de detección (Frisk et 
Cuadro 1. Signos clínicos en canes sospechosos de distemper en el momento de la toma de muestra

\begin{tabular}{|c|c|}
\hline Categorías & Descripción \\
\hline I & $\begin{array}{l}\text { Animales que pueden presentar depresión, inapetencia, pérdida de peso, } \\
\text { deshidratación fiebre, inflamación de ganglios linfáticos, secreciones } \\
\text { conjuntivales, nasales, tos, diarreas, vómitos, y dermatitis pustular (signos } \\
\text { sistémicos). }\end{array}$ \\
\hline II & $\begin{array}{l}\text { Animales que pueden presentar ataxia, paresia, parálisis, convulsiones, } \\
\text { sialorrea contracciones involuntarios (tics nerviosos, fasciculaciones, } \\
\text { movimientos masticatorios), pedaleo, micción involuntaria, defecación, } \\
\text { hiperestesia, vocalización, tambaleo e inestabilidad (signos nerviosos). }\end{array}$ \\
\hline III & $\begin{array}{l}\text { Animales que pueden presentar tanto los signos descritos en el grupo I como } \\
\text { los del grupo II. }\end{array}$ \\
\hline IV & $\begin{array}{l}\text { Animales con los signos descritos en el grupo I y con hiperqueratosis nasal } \\
\text { y/o plantar. }\end{array}$ \\
\hline V & $\begin{array}{l}\text { Animales con los signos descritos en el grupo II y con hiperqueratosis nasal } \\
\text { y/o plantar. }\end{array}$ \\
\hline VI & $\begin{array}{l}\text { Animales con los signos descritos tanto del grupo I y II, y con hiperqueratosis } \\
\text { nasal y/o plantar. }\end{array}$ \\
\hline
\end{tabular}

Cuadro 2. Signos clínicos sistémicos observados en canes sospechosos de distemper en el momento de la toma de muestra

\begin{tabular}{cl}
\hline $\begin{array}{c}\text { Sub- } \\
\text { categorías }\end{array}$ & Signos sistémicos \\
\hline 1 & Respiratorios y digestivos \\
2 & Solo respiratorios \\
3 & Solo digestivos \\
\hline
\end{tabular}

al., 1999; Sarute et al., 2014). Esto podría deberse al hecho de que la detección de ácidos nucleicos virales en sangre periférica depende de factores como el tiempo de infección del individuo y la presencia de anticuerpos neutralizantes (Frisk et al., 1999). Se sabe que la etapa de viremia dura cerca de nueve días, tiempo en que los títulos virales llegan a sus máximos niveles, y que luego de este tiempo los virus alcanzan los órganos objetivo y, además, se inicia la respuesta inmune humoral y celular (Craig, 2000; Rudd et al., 2006; Lorenzana, 2008), con el correspondiente descenso del número de partículas virales circulantes, de manera que disminuye

Cuadro 3. Distribución de los canes sospechosos de distemper según los signos clínicos observados en el momento de la toma de muestra y su positividad al virus por PCR

\begin{tabular}{ccc}
\hline Categoría & $\begin{array}{c}\text { Total } \\
(\mathrm{n})\end{array}$ & $\begin{array}{c}\text { Positivos } \\
\%\end{array}$ \\
\hline I & 20 & 47.0 \\
II & 3 & 0 \\
III & 12 & 23.5 \\
IV & 13 & 29.4 \\
V & 1 & 0 \\
VI & 3 & 0 \\
\hline \multirow{2}{*}{ Total } & 52 & 100 \\
& & $(\mathrm{n}=17)$ \\
\hline
\end{tabular}


Cuadro 4. Distribución de los canes sospechosos de distemper según los signos clínicos sistémicos observados en el momento de la toma de muestra y su positividad al virus

\begin{tabular}{lcc}
\hline Categoría & $\begin{array}{c}\text { Total } \\
(\mathrm{n})\end{array}$ & $\begin{array}{c}\text { Positivos } \\
\%\end{array}$ \\
\hline $\begin{array}{l}\text { Respiratorios } \\
\text { y digestivos }\end{array}$ & 26 & 64.70 \\
Respiratorios & 11 & $\begin{array}{c}17.65 \\
\text { Digestivos }\end{array}$ \\
\hline \multicolumn{1}{c}{ Total } & 48 & $\begin{array}{c}100 \\
(\mathrm{n}=17)\end{array}$ \\
\hline
\end{tabular}

Cuadro 5. Distribución de los canes sospechosos de distemper según el grupo etario y su positividad al virus

\begin{tabular}{ccc}
\hline $\begin{array}{c}\text { Edad } \\
(\text { meses })\end{array}$ & $\begin{array}{c}\text { Total }^{1} \\
(\mathrm{n})\end{array}$ & $\begin{array}{c}\text { Positivos } \\
\%\end{array}$ \\
\hline $0-1.5$ & 2 & 0 \\
$>1.5-4$ & 36 & 93.75 \\
$>4-12$ & 6 & $\begin{array}{c}6.25 \\
0\end{array}$ \\
$>12$ & 7 & $\begin{array}{c}100 \\
(\mathrm{n}=16)\end{array}$ \\
\hline Total & 51 &
\end{tabular}

${ }^{1}$ No se consideró en el cuadro a un animal positivo con edad no determinada (ND)

Cuadro 6. Distribución de los canes sospechosos de distemper según la estación de presentación y su positividad al virus

\begin{tabular}{ccc}
\hline Estación & $\begin{array}{c}\text { Total }^{1} \\
(\mathrm{n})\end{array}$ & $\begin{array}{c}\text { Positivos } \\
\%\end{array}$ \\
\hline Verano & 15 & 41.18 \\
Otoño & 3 & 5.88 \\
Invierno & 12 & 29.4 \\
Primavera & 22 & 23.5 \\
\hline Total & 52 & $\begin{array}{c}100 \\
(\mathrm{n}=17)\end{array}$ \\
\hline
\end{tabular}

la posibilidad de detección del virus en muestras sanguíneas.

Los 52 animales fueron diagnosticados clínicamente como compatibles a distemper canino, donde la mayoría presentó signos sistémicos (38.4\%). Los signos gastrointestinales, respiratorios (signos sistémicos), frecuentemente asociados a signos nerviosos, son característicos de la presentación clásica del distemper canino; sin embargo, estos signos no están apenas presentes en esta enfermedad, y probablemente no estén presentes en el momento de la admisión del paciente (Amude et al., 2006). Síntomas respiratorios y digestivos pueden ser causados también por otros agentes infecciosos virales y bacterianos y los síntomas neurológicos pueden ser causados por toxoplasmosis o encefalitis infecciosa, siendo reconocidos una variedad de agentes causantes de estos cuadros (Tipold, 1995).

El hecho de que el mayor porcentaje de positivos se observara en animales con signos clínicos sistémicos podría deberse a que el muestreo pudo haberse dado en la primera etapa de la infección (los primeros 7-14 días), fase en la que mayoritariamente no se observan signos nerviosos. Por otro lado, como ya ha sido mencionado, el virus desaparece de la sangre periférica y se pueden obtener resultados de falsos negativos. No obstante, se encontró un porcentaje importante de canes con signos nerviosos $(23.53 \%)$, que también presentaban signos sistémicos, positivos al RTPCR, lo que corrobora la alta sensibilidad de esta técnica.

Dentro de los signos sistémicos, los animales positivos presentaron principalmente problemas digestivos y respiratorios a la vez (Cuadro 4), lo que permite deducir que la mayoría de cepas viscerotrópicas presentarían afinidad por ambos sistemas (digestivo y respiratorio), y en menor medida solo por un sistema (digestivo o respiratorio).

Si bien no hubo diferencia estadística entre animales positivos al CDV según el grupo etario, hubo una mayor proporción en ca- 
nes de 1.5-4 meses de edad (Cuadro 5). Esto se debe a que los cachorros después de los 45 días de nacidos se vuelven más susceptibles a adquirir enfermedades ya que los anticuerpos maternales disminuyen notoriamente (Von Messling et al., 1999; Lorenzana, 2008). La incidencia disminuye drásticamente a partir de los cuatro meses, ya que la mayoría de canes han adquirido cierta inmunidad, sea natural o, en general, la inducida por las vacunas.

En forma similar, se pudo apreciar una mayor incidencia de casos en verano, lo que estaría asociado a un aumento de nacimientos en esa época y, por tanto, incremento de cachorros susceptibles. No obstante, Ettinger (1997) encontró que el grado de presentación es mayor en otoño-invierno.

\section{Agradecimientos}

Los autores expresan su agradecimiento al Vicerrectorado de Investigación y Posgrado de la Universidad Nacional Mayor de San Marcos por haber financiado el Proyecto «Caracterización genética y molecular del virus del distemper canino en caninos domésticos» Código 130801031.

\section{Literatura Citada}

1. Amude AM, Carvalho GA, Balarin MRS, Arias MVB, Faria dos Reis AC, Alfieri AA, Alfieri AF. 2006. Encefalomielite pelo vírus da cinomose canina em cães sem sinais sistêmicos da doença - estudos preliminares em três. Clín Vet 60: 60-66.

2. Barrett T. 1999. Morbillivirus infections, with special emphasis on morbilliviruses of carnivores. Vet Microbiol 69: 3-13. doi: 10.1016/S0378-1135(99)00080-2

3. Beineke A, Puff C, Seehusen F, Baumgärtner W. 2009. Pathogenesis and immunopathology of systemic and nervous canine distemper. Vet Immunol
Immunopathol 127: 1-18. doi: 10.1016/ j.vetimm.2008.09.023

4. Blancou J. 2004. Dog distemper: imported into Europe from South America? Hist Med Vet 29: 35-41.

5. Céspedes P, Cruz P, Navarro C. 2010. Modulación de la respuesta inmune durante la infección por virus distemper canino: implicancias terapéuticas y en el desarrollo de vacunas. Arch Med Vet 42: 15-28. doi: 10.4067/S0301-732X2010000200003

6. Craig E. 2000. Enfermedades infecciosas en perros y gatos. $2^{\mathrm{a}}$ ed. México DF: McGraw-Hill. Interamericana. 1014 p.

7. Deem SL, Spelman LH, Yates RA, Montali RJ. 2000. Canine distemper in terrestrial carnivores: a review. J Zoo Wildl Med 31: 441-451. doi: 10.1638/ 1042 - $7260(2000) 031$ [ 0441 : CDITCA]2.0.CO;2

8. Ettinger $S$. 1997. Tratado de medicina interna. Enfermedades del perro y el gato. Buenos Aires: Inter Médica. p 234239.

9. Fenner F, Bachmann P, Gibbs E, Murphy F, Studert M, White D. 1992. Virología veterinaria. Zaragoza, España: Acribia. $691 \mathrm{p}$.

10. Frisk AL, König M, Moritz A, Baumgärtner $W$. 1999. Detection of canine distemper virus nucleoprotein RNA by reverse transcription-PCR using serum, whole blood, and cerebrospinal fluids from dogs with distemper. J Clin Microbiol 37: 3634-3643.

11. Gámiz C, Martella V, Ulloa R, Fajardo $R$, Quijano-Hernandez I, Martínez $S$. 2011. Identification of a new genotype of canine distemper virus circulating in America. Vet Res Commun 35: 381-390. doi: 10.1007/s11259-011-9486-6

12. Greene CE. 2012. Infectious diseases of the dog and cat. $4^{\text {th }}$ ed. St. Louis, MO, USA: Elsevier/Saunders. $1376 \mathrm{p}$.

13. Józwik A, Frymus T. 2002. Natural distemper virus in vaccinated and unvaccinated dogs in Warsaw. J Vet Med B Infect Dis Vet Public Health 49: 413-414. doi: 10.1046/j.1439-0450.2002.-00549.x 
14. Lorenzana L. 2008. Actualización en la terapéutica del moquillo canino. Uso del interferón recombinante. México: Virbac N. ${ }^{\circ}$ II. [Internet]. Disponible en: http://www.webveterinaria.com/virbac/ news13/pequenas.pdf

15. Martella V, Elia G, Buonavoglia $C$. 2008. Canine distemper virus. Vet Clin North Am Small Anim Pract 38: 787-797. doi: 10.1016/j.cvsm.2008.02.007

16. Mochizuki M, Hashimoto M, Hagiwara S, Yoshida Y, Ishiguro S. 1999. Genotypes of canine distemper virus determined by analysis of the hemagglutinin genes of recent isolates from dogs in Japan. J Clin Microbiol 37: 2936-2942.

17. Panzera Y, Gallo Calderon M, Sarute $N$, Guasco S, Cardeillac A, Bonilla B, Hernandez M, et al. 2011. Evidence of two co-circulating genetic lineages of canine distemper virus in South America. Virus Res 163: 401-404. doi: 10.1016/ j.virusres.2011.10.008

18. Panzera Y, Sarute N, Carrau L, Aldaz J, Pérez R. 2014. Genetic diversity of canine distemper virus in South America. Brit J Virol 1: 48-53.

19. Rudd P, Cattaneo $R$, von Messling $V$. 2006. Canine distemper virus uses both the anterograde and the hematogenous pathway for neuroinvasion. J Virol 80: 9361-9370. doi: 10.1128/JVI.01034-06
20. Sarute N, Perez R, Aldaz J, Alfieri AA, Alfieri AF, Name D, Llanes $J$, et al. 2014. Molecular typing of canine distemper virus strains reveals the presence of a new genetic variant in South America. Virus Genes 48: 474-478. doi: 10.1007/s11262-014-1054-Z

21. Stephensen CB, Welter J, Thaker SR, Taylor J, Tartaglia J, Paoletti E. 1997. Canine distemper virus (CDV) infection of ferrets as a model for testing morbillivirus vaccine strategies: NYVACand ALVAC-based CDV recombinants protect against symptomatic infection. $\mathrm{J}$ Virol 71: 1506-1513.

22. Typold. A. 1995. Diagnosis of inflammatory and infectious diseases of the central nervous system in dogs: a retrospective study. J Vet Intern Med 9: 304-314. doi: 10.1111/j.1939-1676.1995.tb01089.x

23. Veliz A. 2004. Uso de la inmunofluorescencia directa para diagnóstico temprano del virus del distemper canino. Tesis de Médico Veterinario. Lima: Univ. Nacional Mayor de San Marcos. 39 p.

24. Von Messling V, Harder T, Moennig V, Rautenberg P, Nolte I, Haas L. 1999. Rapid and sensitive detection of immunoglobulin $\mathrm{M}$ (IgM) and IgG antibodies against canine distemper virus by a new recombinant nucleocapsid proteinbased enzyme-linked inmuno-sorbent Assay. J Clin Microbiol 37: 1049-1056. 